\title{
Gender Differences in the Academic Performance of Students
}

\author{
Mankumari Parajuli \\ School of Development and Social Engineering \\ Pokhara University \\ Email: mankumaripjl@gmail.com \\ Ajay Thapa \\ School of Development and Social Engineering \\ Pokhara University \\ Email: azaythapa@gmail.com
}

\begin{abstract}
This study aimed to examine gender differences in the academic performance of students. The data were collected from 240 students who passed the district level standard exam of grade eight in 2016 and were studying in grade nine in public and private schools in Lekhnath Municipality, Kaski, Nepal. The data on the characteristics of students, their parents, students' behavior, perceptions, family environment, school environment were collected from the students, and their parents, and teachers using a structured questionnaire. The data on student's results and divisions scored by students as measures of academic performance of the students were obtained from the District Education Office (DEO) of Kaski. The study found significant gender differences in the academic performance of students. The female students were found outperforming their male counterparts. The study also revealed that a large majority of the students scored first division or higher with relatively an outstanding performance by private schools compared to public schools. The students of private schools seem to perform better in task completion, attendance and assertiveness as well.
\end{abstract}

Keywords: Academic performance, gender difference, public school, private school

\section{Introduction}

Gender refers to socially constructed differences between male and female. Scholars, policymakers, and practitioners have observed and seem to agree upon socially constructed differences between male and female and its significant effects in their lives. Studies conducted across the world among the students studying in different levels found a significant gender difference in academic performance. Several studies have reported that female students outperform their male counterparts (Orabi, 2007; Dayioglu \& Turut, 2007; Khwaileh \& Zaza, 2010). Ghazvini \& Khajehpour (2011) further argued that even gender difference exists at the level of cognitive functioning in the academic environment. Girls are likely to be more adaptive in learning in a different environment. However, Wangu (2014) in a study conducted among the students of secondary schools in Kenya observed boys passing more than girls. On the other hand, Goni et al. (2015) in a study conducted among college-going students did not observe the significant gender difference in academic performance.

Studies have also observed gender inequality in the classroom because of instructional design during teaching and learning process. Sometimes, teachers tend to unconsciously adopt stereotypical

Journal of Development and Social Engineering

Volume 3 | Number 1 | December 2017, 39-47

ISSN 2382-5332 (C) School of Development and Social Engineering, Pokhara University 
routine or practice that separates boys and girls. Knupfer (1997:34) stated, "Teachers still persist in the practice of performing lines, determining groups and awardwinning prizes by gender". Similarly, Spender (1982) argued that teachers tend to give different types of attention to boys and girls. According to Spender, girls are praised for their appearance, good behavior and neat work. Gibbs (1994) stated that boys talk more than girls in the classroom. It seems even associated with the values of a person or society. For example, when boys call out teachers, it seems acceptable whereas when a girl calls out, she is sometimes scolded and is told that calling out teacher by a girl is not an appropriate behavior. This strongly indicates that boys should be more assertive and girls should be passive which may lead to poor performance and failure in girls.

In a country like Nepal where patriarchy is still dominant in various aspects of life, gender differences are still clearly evident. The social status of women/girl in Nepal is generally low, a situation attributable to both the general poverty of the country and the gender-based distribution of power and resources in the family and in society. Nepalese women, in general, have not been able to become active participants in development activities due to illiteracy, poor health, poverty, traditionally conservative attitude towards them and lack of their access to productive resources and information and technology. Discrimination against women/ girl begins right from birth. The religious, cultural, traditional beliefs and political scenario promote such discrimination. As a result, wide gender disparity is seen in every sphere of national development.

Education for all has been a good slogan of the government of Nepal. Furthermore, expanding opportunities for and accessibility of women/girl in education has been one of the objectives of the education sector under different national development plans of Nepal. The government of Nepal has received grants from various international organizations like United Nations, World Bank, Danish International Development Agency (DANIDA), Government of Finland, Norwegian Agency for Development Cooperation (NORAD), and Department for International Development (DFID), etc. to strengthen gender equality in various aspects of lives of the people across the country. In this context, the Government of' Nepal, NGOs, and INGOs have been concentrating on ensuring complete free, equitable and quality primary and secondary education leading to relevant and effective learning outcomes for all girls and boys by 2030 as guided by the Sustainable Development Goals (UNO, 2015).

Despite vigorous efforts from the government and non-government sectors to ensure gender equality in education, there is still a serious gap between boys and girls in academic performance and achievement. There are very limited studies focused on the issues of gender differences in academic performance of students. There are several issues of gender inequalities in education not much answered in Nepal such as how is the academic performance of students in exam?, does gender matter in the academic performance?, is there any difference in the student's academic performance between public and private schools?, and do family environment and school environment have significant effects on the gender differences in students' academic performance? Hence, this study aims to examine the gender differences in the academic performance of students in the Nepalese context.

\section{Data and Methods}

For the purpose of this study, data were collected from both primary and secondary sources. Primary data were enumerated from the students who passed the district level standard exam of grade eight in 2016, their class teachers and parents. The primary data includes the data related to personal information: age, sex, religion, caste and ethnicity, family size, family income, and parent's education as well as data/ 
information related to student's behavior, family environment and school environment. Student's results such as division or percentage scored in the exam were used as measures of academic performance. The data on student's academic performance were obtained from the District Education Office (DEO), Kaski.

According to the record obtained from District Education Office (DOE), Kaski the total number of students completing grade eight in the year 2016/17 from Lekhnath Municipality was 869 . The sample size, given the $5.4 \%$ margin of error, $95 \%$ confidence level, $50 \%$ response distribution and the population 869 , is estimated to be 240 .

The respondents for this study were sampled from both public and private schools as well as male and female students representing $50 \%$ in each category. The schools were selected purposively with quota for both public and private schools. The necessary data for the study were enumerated from the students of grade eight, their parents and their teachers.

\section{Results and Discussion \\ Socio-demographic and economic characteristics of the students}

The socio-demographic and economic characteristics of the students include age, gender, caste/ethnicity, religious affiliation, family occupation, monthly income of their family, and education of their mothers and fathers. Half of the respondents (50\%) were female and the rest were male (50\%). The mean age of respondents was 14.71 years (SD: 0.895). The minimum age of respondents was 12 years and the maximum was 18 year. More than one-third of the respondents (38.75\%) were Brahmin/ Chhetri followed by Janajati (38.33\%), Dalit (22.08\%), and others (0.83\%) respectively. A great majority of them $(83.75 \%)$ were Hindu followed by Buddhist (14.17\%), Christian (1.67\%) and others $(0.42 \%)$ (table 1$)$.

About one-third of the total respondents' major family occupation was foundagriculture (29.58\%) followed by business (27.50\%) and service (13.33\%). Rest of the respondents' family occupation was others, which seems to include job, foreign employment, labour (29.58\%). Regarding the economic status of the respondents, nearly half of them (45.8\%) belonged to the lowest quartile followed by second quartile (40.40\%), the highest quartile $(7.9 \%)$ and third quartile $(5.8 \%)$ respectively. A great majority of the students' fathers were $(86.67 \%)$ were literate while about three fourth of their mothers $(77.92 \%)$ were literate (table 1).

Table 1: Socio-demographic characteristics wise distribution of the respondents (n=240)

\begin{tabular}{lcc}
\hline Variables & $\mathbf{N}$ & \% \\
\hline Gender & & \\
Male & 120 & 50 \\
Female & 120 & 50 \\
\hline Age group & 19 & 8.00 \\
Early adolescent (10- 13 yrs) & 186 & 77.40 \\
Middle adolescent (14- 15 yrs) & 35 & 14.60 \\
Late adolescent (16- 19 yrs) & & \\
Mean \pm SD (Min, Max): $14.71 \pm 0.895 ;(12,18)$ & & 38.75 \\
Caste/ethnicity & 93 & 38.33 \\
Brahmin/Chhetri & 92 & 22.08 \\
Janajati & 53 & 0.83 \\
Dalit & 2 & \\
Other & & \\
\hline
\end{tabular}




\begin{tabular}{lcc}
\hline Variables & $\mathbf{N}$ & $\mathbf{\%}$ \\
\hline Religion & 201 & 83.75 \\
Hindu & 34 & 14.17 \\
Buddhist & 4 & 1.67 \\
Christian & 1 & 0.42 \\
Other & & \\
\hline Family occupation & 71 & 29.58 \\
Agriculture & 66 & 27.50 \\
Business & 32 & 13.33 \\
Service & 71 & 29.58 \\
Other & & \\
\hline Monthly family income & 110 & 45.80 \\
Lowest quartile & 97 & 40.40 \\
Second quartile & 14 & 5.80 \\
Third quartile & 19 & 7.90 \\
Highest quartile & & \\
Mean(Min, Max) $35637.50(6000,200000)$ & & 13.33 \\
\hline Father's education & 32 & 86.67 \\
Illiterate & 208 & \\
Literate & & 22.08 \\
\hline Mother's education & 53 & 77.92 \\
Illiterate & 187 & \\
Literate & & \\
Source: Field Survey, 2017 & & \\
& & \\
\hline
\end{tabular}

\section{School environment}

Table 2 revealed the information about the school's environment. Half of the students (50\%) were from the public schools and the rest of them were from private schools. More than two-thirds of the students were found moderately satisfied (Good $=70.83 \%$ ) with the school infrastructure like school building followed by moderately dissatisfied (Not so well $=17.92 \%$ ) and highly satisfied (Very good $=11.25 \%$ ). Over one-third of the students were found dissatisfied with the condition of the science lab and library (poor condition $=34.58 \%$ ), followed by the response of not enough materials in the science lab and library (32.08\%). More than half of the students (58.33\%) said that their schools had modern technology related to teaching and learning but didn't use the technology frequently.

Almost all the teachers were punctual and regular in the classrooms. A significantly great majority of the teachers (92.08\%) were found not discriminating between girls and boys. However, as per the students' perception, the remaining percentage of the teachers $(7.92 \%)$ was found caring and supporting more to the girls than boys.

The result of this study seems to contradict with the findings of previous studies like Gibbs (1994). Gibbs (1994) pointed out teacher's gendered behavior where teachers seem to give priority to male students than females. There might be several reasons behind such results of this study. One of the reasons could be the cultural and contextual difference of the place where the study was conducted. In the Nepalese context, girls are paid more attention as well as greater sympathy by culture and religious values as well. Girls traditionally in several festivals are considered as goddesses. Unconsciously such cultural and religious values might have guided teachers to slightly favor or support female students. 
Table 2: Information regarding schools and school's environment $(n=240)$

\begin{tabular}{|c|c|c|}
\hline Variables & $\mathbf{N}$ & $\%$ \\
\hline \multicolumn{3}{|l|}{ Type of school } \\
\hline Public & 120 & 50.00 \\
\hline Private & 120 & 50.00 \\
\hline \multicolumn{3}{|l|}{ School infrastructure } \\
\hline Not so good & 43 & 17.92 \\
\hline Good & 170 & 70.83 \\
\hline Very good & 27 & 11.25 \\
\hline \multicolumn{3}{|l|}{ Situation of science lab and library } \\
\hline No library and science lab & 45 & 18.75 \\
\hline Is in poor condition & 83 & 34.58 \\
\hline No enough materials & 77 & 32.08 \\
\hline Sufficient materials and well managed & 35 & 14.58 \\
\hline \multicolumn{3}{|c|}{$\begin{array}{l}\text { Use of modern technology in teaching and } \\
\text { learning process }\end{array}$} \\
\hline Yes & 100 & 41.67 \\
\hline No & 140 & 58.33 \\
\hline \multicolumn{3}{|l|}{ Frequency of using modern technology } \\
\hline Sometime & 58 & 58.00 \\
\hline Mostly & 37 & 37.00 \\
\hline Always & 5 & 5.00 \\
\hline \multicolumn{3}{|c|}{$\begin{array}{l}\text { Regularity/punctuality of the teacher in the } \\
\text { classroom }\end{array}$} \\
\hline Yes & 239 & 99.58 \\
\hline No & 1 & 0.42 \\
\hline \multicolumn{3}{|l|}{ Teacher's behavior to the students } \\
\hline Behaves equal to both gender & 221 & 92.08 \\
\hline Favors one gender & 19 & 7.92 \\
\hline \multicolumn{3}{|l|}{ Teacher's support/favor to students } \\
\hline Boys & 2 & 10.53 \\
\hline Girls & 17 & 89.47 \\
\hline
\end{tabular}

Source: Field Survey, 2017

Academic performance of the students

Table 3 illustrates the summary of the students' academic performance. A large majority of the students (71.25\%) scored first division or higher in the district level exam of grade eight followed by second division (28.33\%). A very negligible percentage of students $(0.41 \%)$ had pass division.

Table 3: Students' academic performance $(n=240)$

\begin{tabular}{lcc}
\hline Division & N & \% \\
\hline Pass division & 1 & 0.41 \\
Second division & 68 & 28.33 \\
First division & 97 & 40.42 \\
Distinction & 74 & 30.83 \\
\hline
\end{tabular}

Source: DEO, Kaski, 2017 


\section{Types of school and academic performance}

Academic performance of the students in this study was assessed through the percentage and/or divisions scored by the student in the district level exam of grade eight. Table 4 revealed that the academic performance of private schools is better than their government counterparts. A significantly great majority of the students studying in private schools (98.33\%) passed the district level exam of grade eight in first division or higher whereas only about two fifths $(43.72 \%)$ of the students studying in public schools stood in such position. In the context of public schools, more than half of the total students (55\%) passed in the second division, which is negligible in the case of private schools $(1.69 \%$ ) (table 4 ).

Table 4: Academic performance of public and private schools

\begin{tabular}{ccccccccc}
\hline & \multicolumn{7}{c}{ Student's percentage } \\
\cline { 2 - 9 } Types of school & Pass division & Second division & First division & \multicolumn{1}{c}{ Distinction } \\
\cline { 2 - 9 } & $\mathbf{N}$ & $\mathbf{\%}$ & $\mathbf{N}$ & $\mathbf{\%}$ & $\mathbf{N}$ & $\mathbf{\%}$ & $\mathbf{N}$ & $\mathbf{\%}$ \\
\hline Public School & 1 & 0.83 & 66 & 55 & 44 & 36.67 & 9 & 7.5 \\
\hline Private School & 0 & 0 & 2 & 1.67 & 53 & 44.17 & 65 & 54.16 \\
\hline
\end{tabular}

The better results in the private schools compared to public schools might be due to greater regularity of students in the class, assigned task completion ratio and assertiveness in private schools compared to public schools) having good facilities in private school like sufficient materials in library and science lab, using modern technology and actively involving the students in discussion. This explanation is supported by the following results as well. For example, only a few students in public schools $(16.67 \%)$ were found often completing the tasks assigned by the teachers, which figure was more than double (35.83\%) in private schools.

Similarly, over one-third of the students $(34.17 \%)$ were irregular in public school whereas only a very few of the students $(5.83 \%)$ were irregular in private schools (table 5). In the same way, the students from private schools were found more assertive than their public counterparts. The students of private schools were found more active $(66.22 \%)$ compared to the students of public schools (55.0\%) (table 5).

Table 5: Task completion, attendance and assertiveness of students

\begin{tabular}{|c|c|c|c|c|c|c|c|c|}
\hline \multirow{3}{*}{$\begin{array}{c}\text { Types of } \\
\text { school }\end{array}$} & \multicolumn{8}{|c|}{ Task completion } \\
\hline & \multicolumn{2}{|c|}{ Never } & \multicolumn{2}{|c|}{ Rarely } & \multicolumn{2}{|c|}{ Sometime } & \multicolumn{2}{|c|}{ Often } \\
\hline & $\mathbf{N}$ & $\%$ & $\mathbf{N}$ & $\%$ & $\mathbf{N}$ & $\%$ & $\mathbf{N}$ & $\%$ \\
\hline Public School & 7 & 5.83 & 20 & 16.67 & 33 & 27.5 & 34 & 16.67 \\
\hline Private School & 0 & 0 & 4 & 3.33 & 29 & 24.17 & 43 & 35.83 \\
\hline \multirow{3}{*}{$\begin{array}{c}\text { Types of } \\
\text { school }\end{array}$} & \multicolumn{8}{|c|}{ Attendance } \\
\hline & \multicolumn{4}{|c|}{ Regular } & \multicolumn{4}{|c|}{ Irregular } \\
\hline & \multicolumn{2}{|c|}{$\mathbf{N}$} & \multicolumn{2}{|c|}{$\%$} & \multicolumn{2}{|c|}{$\mathbf{N}$} & \multicolumn{2}{|c|}{$\%$} \\
\hline Public School & \multicolumn{2}{|c|}{79} & \multicolumn{2}{|c|}{65.8} & \multicolumn{2}{|c|}{41} & \multicolumn{2}{|c|}{34.17} \\
\hline Private School & \multicolumn{2}{|c|}{113} & \multicolumn{2}{|c|}{94.17} & \multicolumn{2}{|c|}{7} & \multicolumn{2}{|c|}{5.83} \\
\hline
\end{tabular}




\begin{tabular}{cccccccccccc}
\hline \multirow{2}{*}{$\begin{array}{c}\text { Types of } \\
\text { school }\end{array}$} & \multicolumn{10}{c}{ Assertiveness } \\
\cline { 2 - 12 } & Vary Passive & \multicolumn{1}{c}{ Passive } & Not so active & Active & \multicolumn{1}{c}{ Very active } \\
\cline { 2 - 12 } & $\mathbf{N}$ & $\mathbf{\%}$ & $\mathbf{N}$ & $\mathbf{\%}$ & $\mathbf{N}$ & $\mathbf{\%}$ & $\mathbf{N}$ & $\mathbf{\%}$ & $\mathbf{N}$ & $\%$ \\
\hline Public School & 6 & 5 & 8 & 6.67 & 40 & 33.33 & 53 & 44.17 & 13 & 10.83 \\
\hline Private School & 0 & 0 & 4 & 3.33 & 36 & 30.00 & 57 & 47.5 & 23 & 19.17 \\
\hline
\end{tabular}

Source: Field Survey, 2017

\section{Gender differences in academic performance}

Analyzing gender difference in the academic performance was the main objective of the study. With reference to this objective, the study found that among the students scoring distinction position in the district level standard exam of grade eight, females hold a significantly greater percentage (38.33\%) compared to their male counterparts (23.33\%). However, among the students passed in first division, the percentage of male students was relatively greater $(47.50 \%)$ compared to female students (33.33\%). Below the first division, the difference between male and female seems negligible (table 6).

Table 6: Gender difference in academic performance $(n=240)$

\begin{tabular}{lcccccccc}
\hline & \multicolumn{8}{c}{ Academic performance } \\
\cline { 2 - 9 } Gender & Pass division & \multicolumn{1}{c}{ Second division } & First division & \multicolumn{2}{c}{ Distinction } \\
\cline { 2 - 9 } & $\mathbf{N}$ & $\mathbf{\%}$ & $\mathbf{N}$ & $\mathbf{\%}$ & $\mathbf{N}$ & $\mathbf{\%}$ & $\mathbf{N}$ & $\%$ \\
\hline Male & 1 & 0.08 & 34 & 29.17 & 57 & 47.50 & 28 & 23.33 \\
\hline Female & & & 34 & 29.17 & 40 & 33.33 & 46 & 38.33 \\
\hline
\end{tabular}

Source: DEO, Kaski, 2017

Furthermore, the statistical association between student's gender and their academic performance was examined by running the chi-square test. Due to the less number of cases than required for the chi-square test in pass division category, the pass division and second division were merged in a group - "second division \& below". The upper categories - first division and distinction were also merged in a group - "first division \& above" (table 7).

Table 7: Association between gender and student's academic performance $(n=240)$

\begin{tabular}{lcccc}
\hline \multirow{2}{*}{ Gender } & \multicolumn{4}{c}{ Academic performance } \\
\cline { 2 - 4 } & Second division \& below & First division \& above & Chi-square & P-value \\
\hline Male & $35(29.17 \%)$ & $85(70.83 \%)$ & \multirow{2}{*}{1.000} & $0.004^{*}$ \\
\hline Female & $34(28.33 \%)$ & $86(71.67 \%)$ & & \\
\hline
\end{tabular}

Source: DEO, Kaski, 2017

The study found a significant association between student's gender and their academic performance $\left(\lambda^{2}=1.00, \mathrm{df}=1, \mathrm{p}<0.05\right.$, table 7$)$. The statistical significance with a relatively greater percentage of female scoring first division and above (71.67\%) compared to their male counterparts $(70.83 \%)$ indicates that female students outperformed male students. The results of this study seem to support the findings of some of the previous studies such as Orabi (2007), Dayioglu \& Turut (2007), Khwaileh \& Zaza (2010) who 
have identified significant gender differences in the academic performance of students especially female students outperforming their male counterparts. Meanwhile, the results also seem to reject the findings of some other scholars like Wangu (2014) who claimed that male students outperform their female counterparts and Goni et al. (2015) who claimed that there is no such significant gender difference in student's academic performance. Despite being a dominantly patriarchal society in Nepal, the finding of this study like female outperforming their male counterparts seems interesting. There might be several reasons behind such results. For instance, over the last 3 decades, there are several government policies as well as non-governmental organizations and civil societies sensitizing girls and/or females more in education, skill development, career development, women's rights, women independence and so on. Females also seem to have limited choices, therefore, performing better in education appears to be more important. The parents of the girls might be more sensitive in ensuring the better education for their career and better future. Similarly, boys tend to involve more in several other extracurricular activities than girls, therefore, after schools, the girls can have more time for their assignment or to complete assigned tasks by teachers and study at home and schools as well, thereby resulting in better academic performance than boys.

\section{Conclusion}

Along with the emergence of Gender and Development (GAD) approach in the 1980s, applying the gender perspective in policymaking, implementation, and evaluation as well as in doing social research has become a focus of policymakers, bureaucrats, consultants, practitioners and social scientists all around the world, therefore the academic field is not an exception. Several local, national and international efforts have been made to strengthen equality in access to quality education the disadvantaged, marginalized and minority population. In this context, using the primary data collected from 240 students of public and private schools who passed district level standard exam of grade eight in 2016 as well as secondary data on the academic performance of students obtained from the District Education Office (DEO), Kaski, this study mainly examined the gender difference in academic performance of the students. The study found that a large majority of the students scored first division or higher in the exam with relatively an outstanding performance by private schools compared to public schools in as aspects of academic performance such as results, task completion, attendance and assertiveness. The study concludes that gender matters in the academic performance of students. The female students seem to outperform their male counterparts.

\section{Acknowledgements}

This study is based on the data collected for the Master's Degree dissertation of the first author. The data were further scrutinized and edited as required for the purpose of this journal paper. The dissertation has been submitted to the School of Development and Social Engineering, Faculty of Humanities and Social Sciences, Pokhara University in 2017.

\section{References}

Dayioglu, M. \& Turut, S. (2007). Gender differences in academic performance in a large public university in Turkey. Higher Education, 53(2): 255-277. (Available at https://doi.org/10.1007/ s10734-005-2464-6).

Ghazvini, S.D. and Khajehpour, M. (2011). Gender differences in factors affecting academic performance of high school students. Procedia - Social and Behavioral Sciences, 15: 1040-1045.

Gibbs, J. (1994). Tribes: A new way of learning and being together. Sausalito, CA: Center 
Source Systems

Goni, U., Yaganawali S.B., Ali, H.K., Bularafa, M.W. (2015). Gender differences in students' academic performance in Borno State, Nigeria: Implications for counseling. Journal of Education and Practice, 6(32):107-114. (Available at www.iiste.org).

Khwaileh, F. and Zaza, H. (2010). Gender differences in academic performance among undergraduates at the University of Jordan: Are they real or stereotyping? College Student Journal, 45.

Knupfer, N. N. (1997). Gendered by Design. British Journal of Educational Technology. 37 (2), pp. 31-37.

Orabi, I. (2007). Gender differences in student academic performance and attitudes. American Society for Engineering Education (Available at https://peer. asee. $\quad$ org/gender-differences-instudent-academic-performance-andattitudes. pdf)

Spender, D. (1982). Invisible women: The school scandal. London: The Women's Press.

UNO (2015). Transforming Our World: The 2030 Agenda for Sustainable Development, UN, New York.

Wangu, M.J. (2014). The impact of gender differences on student's academic performance in secondary schools in Ndumberi division, Kiambu county, Kenya in science subjects and languages. A Research Project Submitted In Partial Fulfillment Of The Requirement For The Award Of The Postgraduate Diploma In Education Of University Of Nairobi. (Available at http://erepository.uonbi. ac.ke). 